\title{
Front Matter: Volume 9196
}

, "Front Matter: Volume 9196," Proc. SPIE 9196, Systems Contamination: Prediction, Measurement, and Control 2014, 919601 (30 September 2014); doi: $10.1117 / 12.2085356$

SPIE Event: SPIE Optical Engineering + Applications, 2014, San Diego, California, SPIE. United States 


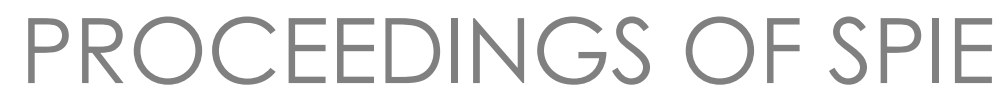

\title{
Systems Contamination: Prediction, Measurement, and Control 2014
}

\author{
Nancy Carosso \\ Joanne Egges \\ Editors
}

\section{8-19 August 2014}

San Diego, California, United States

Sponsored and Published by

SPIE 
The papers included in this volume were part of the technical conference cited on the cover and title page. Papers were selected and subject to review by the editors and conference program committee. Some conference presentations may not be available for publication. The papers published in these proceedings reflect the work and thoughts of the authors and are published herein as submitted. The publisher is not responsible for the validity of the information or for any outcomes resulting from reliance thereon.

Please use the following format to cite material from this book:

Author(s), "Title of Paper," in Systems Contamination: Prediction, Measurement, and Control 2014, edited by Nancy Carosso, Joanne Egges, Proceedings of SPIE Vol. 9196 (SPIE, Bellingham, WA, 2014) Article CID Number.

ISSN: 0277-786X

ISBN: 9781628412239

Published by

SPIE

P.O. Box 10, Bellingham, Washington 98227-0010 USA

Telephone +1 3606763290 (Pacific Time) · Fax +1 3606471445

SPIE.org

Copyright (@ 2014, Society of Photo-Optical Instrumentation Engineers.

Copying of material in this book for internal or personal use, or for the internal or personal use of specific clients, beyond the fair use provisions granted by the U.S. Copyright Law is authorized by SPIE subject to payment of copying fees. The Transactional Reporting Service base fee for this volume is $\$ 18.00$ per article (or portion thereof), which should be paid directly to the Copyright Clearance Center (CCC), 222 Rosewood Drive, Danvers, MA 01923. Payment may also be made electronically through CCC Online at copyright.com. Other copying for republication, resale, advertising or promotion, or any form of systematic or multiple reproduction of any material in this book is prohibited except with permission in writing from the publisher. The CCC fee code is 0277-786X/14/\$18.00.

Printed in the United States of America.

Publication of record for individual papers is online in the SPIE Digital Library.

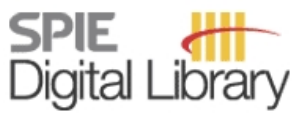

SPIEDigitalLibrary.org

Paper Numbering: Proceedings of SPIE follow an e-First publication model, with papers published first online and then in print and on CD-ROM. Papers are published as they are submitted and meet publication criteria. A unique, consistent, permanent citation identifier (CID) number is assigned to each article at the time of the first publication. Utilization of CIDs allows articles to be fully citable as soon as they are published online, and connects the same identifier to all online, print, and electronic versions of the publication. SPIE uses a six-digit CID article numbering system in which:

- The first four digits correspond to the SPIE volume number.

- The last two digits indicate publication order within the volume using a Base 36 numbering

system employing both numerals and letters. These two-number sets start with 00, 01, 02, 03, 04, $05,06,07,08,09,0 A, 0 B \ldots$. 0Z, followed by 10-1Z, 20-2Z, etc.

The CID Number appears on each page of the manuscript. The complete citation is used on the first page, and an abbreviated version on subsequent pages. Numbers in the index correspond to the last two digits of the six-digit CID Number. 


\title{
Contents
}

\author{
$\checkmark$ Authors \\ vii Conference Committee \\ ix Radiance and photon noise: imaging in geometrical optics, physical optics, quantum \\ optics and radiology (Plenary Paper) [9193-200] \\ xxvii Optical design for consumer products (Plenary Paper) [9197-201]
}

\section{CONTAMINATION CONTROL METHODS I}

919602 Standards activity for contamination control at ASTM and IEST [9196-1]

919603 Surfaces that shed dust: unraveling the mechanisms [9196-3]

919604 Analysis of particulates on tape lift samples [9196-4]

\section{CONTAMINATION CONTROL METHODS II}

919605 Experimental measurement of the reflection behavior of contaminant molecules [9196-5]

919606 Diffusion of water into purged volumes [9196-6]

919607 Identification of collected volatile condensable material (CVCM) from ASTM E595 of silicone damper fluid [9196-7]

\section{CONTAMINATION ANALYTICAL METHODS I}

919608 Molecular transport modeling for spaceborne instrument contamination prediction [9196-8]

$91960 \mathrm{~A}$ Evaluating the bakeout effectiveness of RTV-S691 silicone adhesive by measuring outgassing rate [9196-10]

9196 OB Quantitative model of the effects of contamination and space environment on in-flight aging of thermal coatings [9196-11]

\section{CONTAMINATION ANALYTICAL METHODS II}

9196 OD Ozone Mapping and Profiler Suite: using mission performance data to refine predictive contamination modeling [9196-13] 
$9196 \mathrm{OE} \quad$ Spacecraft materials $\mathrm{HCl}$ susceptibility assessments [9196-16]

9196 OF Black molecular adsorber coatings for spaceflight applications [9196-17]

9196 OG Optical characterization of photofixed RTV effluent in an atomic oxygen atmosphere [9196-18]

$9196 \mathrm{OH}$ Optical and re-emission behavior of silicone contaminants affected by UV irradiation with different wavelength ranges [9196-19]

PROJECT CONTAMINATION

9196 OK Contamination control requirements implementation for the James Webb Space Telescope (JWST), part 1: optics, instruments, and thermal vacuum testing [9196-22]

$9196 \mathrm{OL}$ Contamination control requirements implementation for the James Webb Space Telescope (JWST), part 2: spacecraft, sunshield, observatory, and launch [9196-23] 


\section{Authors}

Numbers in the index correspond to the last two digits of the six-digit citation identifier (CID) article numbering system used in Proceedings of SPIE. The first four digits reflect the volume number. Base 36 numbering is employed for the last two digits and indicates the order of articles within the volume. Numbers start with 00, 01, 02, 03, 04, 05, 06, 07, 08, 09, OA, OB...0Z, followed by 10-12, 20-2Z, etc.

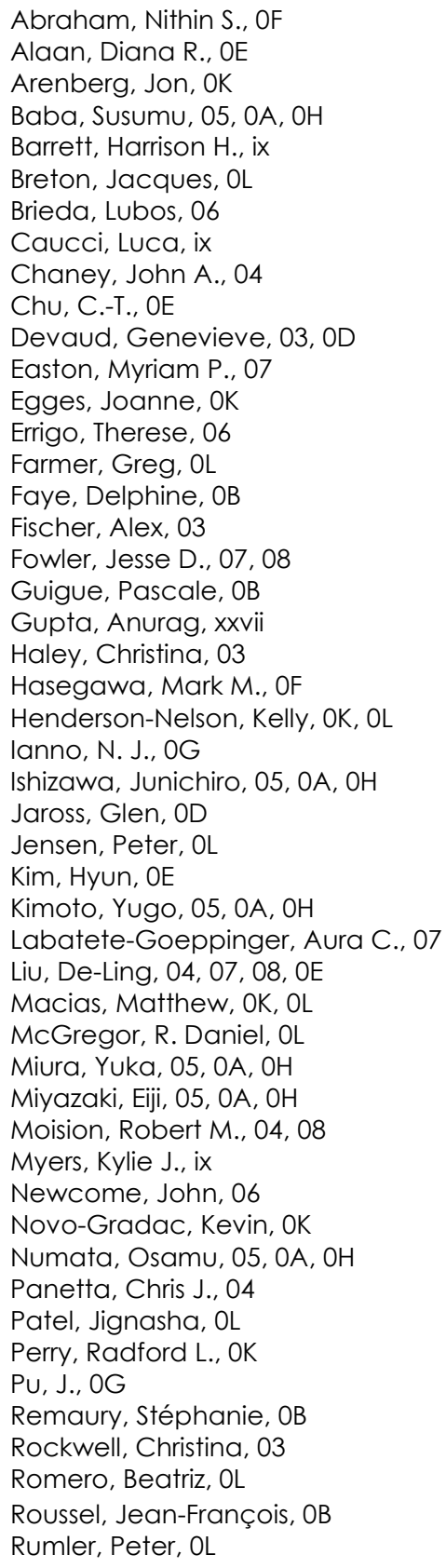

Sanders, Jack T., 02

Schmeitzky, Olivier, OL

Schweiss, Andrea, OL

Straka, Sharon A., OF

Tamura, Takashi, 05, OA, OH

Vanhove, Emilie, $\mathrm{OB}$

Wong, Chung M., 08

Wooldridge, Eve M., OK, OL

Woronowicz, Michael, OK, OL

Yamanaka, Riyo, 05, OA, OH 
Proc. of SPIE Vol. $9196919601-6$

Downloaded From: https://www.spiedigitallibrary.org/conference-proceedings-of-spie on 26 Apr 2023 Terms of Use: https://www.spiedigitallibrary.org/terms-of-use 


\section{Conference Committee}

Program Track Chairs

José Sasián, College of Optical Sciences, The University of Arizona (United States)

R. John Koshel, College of Optical Sciences, The University of Arizona

(United States)

Conference Chairs

Nancy Carosso, NASA Goddard Space Flight Center (United States)

Joanne Egges, Ball Aerospace \& Technologies Corporation (United States)

Conference Program Committee

Nithin S. Abraham, NASA Goddard Space Flight Center (United States)

Jonathan P. Elders, Raytheon Space \& Airborne Systems

(United States)

Matthew Macias, Northrop Grumman Aerospace Systems

(United States)

David P. Taylor, The Aerospace Corporation (United States)

Eve M. Wooldridge, NASA Goddard Space Flight Center

(United States)

Session Chairs

1 Contamination Control Methods I

Eve M. Wooldridge, NASA Goddard Space Flight Center (United States)

2 Contamination Control Methods II

Matthew Macias, Northrop Grumman Aerospace Systems (United States)

3 Contamination Analytical Methods I

David P. Taylor, The Aerospace Corporation (United States)

4 Contamination Analytical Methods II

Jonathan P. Elders, Raytheon Space \& Airborne Systems

(United States)

David P. Taylor, The Aerospace Corporation (United States) 
5 Planetary Protection

Nancy Carosso, NASA Goddard Space Flight Center (United States)

6 Coatings and Molecular Contamination

Nithin S. Abraham, NASA Goddard Space Flight Center (United States)

7 Project Contamination

Joanne Egges, Ball Aerospace \& Technologies Corporation (United States) 